\title{
Anti-VEGFR2 Monoclonal Antibody HLX06
}

National Cancer Institute

\section{Source}

National Cancer Institute. Anti-VEGFR2 Monoclonal Antibody HLXO6. NCI Thesaurus.

Code C156172.

A fully human monoclonal antibody directed ag ainst human vascular endothelial growth factor receptor 2 (VEGFR-2) with potential anti-ang iogenesis and antineoplastic activities. Upon administration, anti-VEGFR2 monoclonal antibody HLX06 specifically binds to and inhibits VEGFR-2, which may inhibit tumor ang iogenesis and tumor cell proliferation.

VEGFR-2, a tyrosine-protein kinase that plays an essential role in angiogenesis and the proliferation, survival, migration and differentiation of endothelial cells, is overexpressed in certain tumor types. 